\title{
Review of Ronald C. Arnett, Levinas's Rhetorical Demand: The Unending Obligation of Communication Ethics
}

Nicholas O. Pagan

Universiti Malaya, Malaysia

SARE: Southeast Asian Review of English, Vol. 54, Issue 1, 2017 


\section{SARE, Vol. 54, Issue $1 \mid 2017$}

\section{Ronald C. Arnett, Levinas's Rhetorical Demand: The Unending Obligation of Communication Ethics. Carbondale: Southern Illinois UP, 2017. xxi + 308 pp. ISBN 978-0-8093-3569-5.}

$\mathbf{T}$ hroughout Ronald Arnett's latest book, the work of Emmanuel Levinas is carefully juxtaposed with that of other prominent thinkers. This is nowhere more apparent than in the last three chapters, all of which deal with Levinas's tortuous relations with Martin Heidegger. Crucially, Arnett highlights a key moment in European twentieth-century intellectual history when he draws attention to the famous debate between Heidegger and Ernst Cassirer that took place in Davos, Switzerland in 1929. As a member of the audience, Levinas found himself siding with Heidegger against Cassirer, and after the debate this preference was reflected in a play staged by students in which Levinas himself indulged in a mocking portrayal of Cassirer. Arnett follows others in drawing attention to the regret that would trouble Levinas throughout and following his lengthy internment in a Nazi concentration camp, a regret eventually reflected most poignantly in his desire to seek out and apologize personally to Cassirer's wife during a trip to New York in 1973. This small detail serves Arnett well in illuminating not only the deep sensitivity of Levinas, the man, but also provides a fine example of Levinas's philosophy in action.

Arnett's Levinas-inspired version of communication ethics involves three rhetorical demands: the face of the Other, an ethical echo, and response to the Other in conjunction with distinctive personal, historical, and social concerns. After the Davos debacle, Levinas was repeatedly haunted by his failure to pay attention to the face of Cassirer, a man whose words exemplified the voice of the human and whose humanity would serve as a synecdoche for all those who would be trampled on and in many cases slaughtered by the Third Reich. Although for Levinas in the early 1930s, Cassirer's voice tended to be drowned out by Heidegger's 'voice of Being,' later Levinas would come to see that his own position had actually always been much closer to Cassirer's. Levinas became acutely conscious that 'humanism' exists primarily not in relation to 'Being' but in relation to an obligation that all human beings share: a responsibility toward the Other. First philosophy, therefore, for Levinas has to consist of ethics, not ontology. As Arnett shrewdly explains, from Levinas's perspective, "Being without a questioning temper of the primacy of ethics is simply dangerous," and Heidegger's "focus on Being eclipses the 'face' of the Other which is ... the primordial counter to elemental evil" $(212,214)$.

It is of course not Cassirer's face in particular but the face of the Other in general that makes Levinas's ethics possible; but as Arnett also explains, "Levinas's eventual recognition of Cassirer's face moved him from being a spectator in a social game that ignored the face of the Other to having an unending ethical obligation" (196). Although as Levinas points out, Heidegger was highly critical of a herd-like mentality, he nevertheless tended to place the 'we' before the 'I.' This relegating of the 'I' to a secondary position meant that Heidegger's philosophy could find no place for a derivative 'I' which, according to Levinas, "is called forth by a separate and distinct Other" (216) which gives birth to ethics.

Arnett paints a convincing picture of Levinas making "the Other which holds the 'I' hostage" as both the starting point of his philosophy and a challenge to the "originative "I" of the West. Levinas is also rightly described as following Immanuel Kant in identifying a need to temper the inclinations of the ego but as going much further than Kant in denouncing the tyranny of reason. Arnett clearly shows Levinas's awareness that "one cannot control the self-centered focus of the ego with an enlightened reasoning" (121). 


\section{SARE, Vol. 54, Issue $1 \mid 2017$}

Arnett also lends support to Levinas's self-definition as a 'phenomenologist.' He repeatedly draws attention to Levinas's substitution of "the phenomenology of the face" for an actual face as hinted at by the declaration in Ethics and Infinity that "[t]he best way of encountering the Other is not even to notice the color of his eyes!" Ignorance concerning the color of the eyes of the Other depersonalizes the Other and rightly suggests that Levinas's desire is to move as rapidly as possible from the personal to the universal. His intention is not to celebrate an egotistical 'I' who relishes the chance to reach out to the hurting, disadvantaged and oppressed, but rather to emphasize that, like it or not, 'I am my brother's keeper.' This assertion is, as Arnett stresses, the fulcrum of Levinas's project: "the ongoing and unending enactment of a phenomenological ethical reality" (60). It is not like one of Kant's versions of the categorical imperatives imposed on the individual as a rule. It is a fact. Whether I actually see my brother face-to-face or whether I have to conjure up his (or her) face with my imagination, "I am my brother's keeper.' I am not, therefore, a post-Enlightenment 'originative I' but a 'derivative I' called upon to answer a request for an ethical responsibility toward another human being.

Arnett stresses the idea in Levinas's work the question of how to respond to the face of the Other cannot be dissociated from the need for justice. The tension between ethics and the call for justice thus becomes the subject-matter of a chapter on Umberto Eco's The Name of the Rose. Levinas's model, according to Arnett, "rejects any polarity between ethics and justice. For it is the tension between them and obligations of both that call forth the life worth living" (148). Arnett shows how following "the Saying of a spiritual awakening" while moderating a dispute between the Franciscans and the papacy, the character William is able to represent "a voice of the Said of justice" (154). Along this path William is able to make use of the library as information-gathering is essential in the interests of justice, but the library in Eco's novel is also the sight of impurity. Perhaps all libraries, like justice itself according to Levinas, are impure? Arnett makes use of Levinas's theory to support the idea that Eco's character can only hope to be successful if he broadens the frame of reference to include not just self and Other but a wide range of disparate often non-present others.

It seems ironical that Arnett approaches Levinas's work through the prism of rhetoric given Levinas's frequently voiced rejection of rhetoric — indeed, the word 'ethics' occurs far more often than the word 'rhetoric' throughout the book; but Arnett justifies his approach by claiming that Levinas "offers an ethics that works rhetorically to demand responsibility from each one of us" (7). Readers of Levinas's Rhetorical Demand may be left wondering how, given the traditional link between rhetoric and persuasion, ethics can ever work otherwise than rhetorically.

Similarly, in Arnett's reading of Levinas, the role of the spiritual is unclear. Although he works strenuously to deny any link between Levinas and mysticism, Arnett frequently locates a spiritual dimension in Levinas's ethics. He claims, for example, that Levinas is able to find "[e]ven in the heart of horrors and barbarities ... traces of a revelatory Saying" (13); and he portrays Levinas's version of ethics as only coming alive when the face or call of the Other is able to trigger in me "a spiritual awakening" that prompts me to boldly respond, "I am here." Although Arnett quite rightly points out that for Levinas (as for Kant) there is no "godhead that determines the validity of individual action" (125), the formulation "I am my brother's keeper" inevitably has a religious echo. Perhaps more credit should be given to the God who often hovers in the margins of these pages, for without Him, and without my acknowledging Him, there may never be any "spiritual awakening" prompting me to respond to the face or call of the Other in the most beautiful and appropriate way imaginable. Despite his reluctance to engage 


\section{SARE, Vol. 54, Issue 1 | 2017}

in depth with the murky question of Levinas's positioning in relation to spirituality, Arnett increases our understanding in particular of how Levinas's call for human beings to acknowledge and act upon their responsibility for the Other is inseparable from the character of Levinas, the man. 